\title{
THE RUTGERS LAW LIBRARY
}

\author{
BY VINCENT E. FIORDALISI
}

Mr. FiordalisI was graduated from Fordham Law School in 1944, and was admitted to the New York bar the same year. After serving as Assistant Law Librarian at the United States Supreme Court Library, he came in 1946 to be Law Librarian and Assistant Professor of Law at the Rutgers Law School.

7 HE LIFE HISTORIES of many law libraries have been written and in all probability have been of interest only to law librarians. Many of them are true "Horatio Alger" stories. The librarians faithfully describe the inauspicious beginnings, the inadequacies and disorders, the lice, termites and rats, both animal and political, and tell how by the superhuman efforts of their staffs the transmutations to respectability were effected. We, too, have "polished up the handles of the big brass doors" in order to develop our law library to its present middle status. But, much too close to the past to look back, we must consider the accomplishments to date only as a preface to the future.

In July, I946, the University of Newark Law Library was incorporated into the Rutgers University Law Library. The firstnamed resulted from a merger of the Mercer Beasley Law School Library with the Library of New Jersey Law School in I 937. A 1936 report of the New Jersey Law School faculty expressed the belief that the combined libraries would not meet the Association of American Law School standards- "minimum requirements for a decent working collection." Each of the libraries had over 6,000 volumes. The Library of the New Jersey Law School, which had been organized in I 909, had 8,020 volumes in I 936, of which only 387 volumes were the property of the Law School. The balance were the property of Mr. Currier. The Mercer Beasley Law Library, organized in I 926, had 6,387 volumes. As of May I, I 942, the holdings of the University of Newark Law Library were reported as I 4,742 volumes. An examination of the accession record for r $942-1946$ indicates a growth of I,22 I volumes for the four-year period.

\section{The Collection and Its Arrangement}

In 1946 the University of Newark was incorporated into the State University of New Jersey maintained by the Trustees of Rutgers College. At that time, the Law Library had a collection of I 6,8 I 2 
volumes. By July, I95 I, five years later, the collection contained over 35,000 bound volumes.

To describe this collection to a member of the legal profession is somewhat akin to telling a chemist that a laboratory contains chemicals, test tubes, and bunsen burners. He has known since he sank his first tooth in a law book that he had several groups of materials to deal with, that most important of these groups was that which constituted "law stuff," primary authority-that constant output of legislative bodies, the stream of opinions of the courts of his own and other jurisdictions, and the endless regulations and decisions of administrative agencies.

Primary authority in the Law Library comprises:

I. Legislation: The current compilation, revision, or code of statutory law of each American jurisdiction (except Utah and Washington which are in the process of revision), together with the session laws subsequent to the publication of the last code, are arranged alphabetically by the jurisdiction in a "statute alcove" in the reading room. The session laws of the several jurisdictions are alphabetically arranged in a stack area. The material designated as legislative accounts for slightly over 3,900 volumes of the Law Library collection.

II. Judicial Opinions: The decisions of the Supreme Court of the United States are available in the official reports, the Lawyers' Edition of the Supreme Court Reports, and the Supreme Court Reporter. The decisions of the inferior federal courts prior to I 880 are available in "Federal Cases." After I 880 they are printed in the Federal Reporter and the Federal Supplement.

The opinions of the New Jersey courts are available in the official reports (N.J. Law Reports, N.J. Equity Reports, N.J. Reports, N.J. Superior Court Reports, and N.J. Miscellaneous Reports [unofficial]) and are also available in the Atlantic Reporter, one of the geographic units of the National Reporter System. The Atlantic Reporter and the other geographic units of the National Reporter System, supply the texts of the judicial opinions of the courts of last resort of the several states from about i 880 to date. For opinions prior to the "National Reporter System" recourse must be had to the so-called "short sets." Except for a few very rare, early and expensive volumes, the library can supply the texts of all decisions of the courts of last resort of the several states. 
The collection of reports accounts for over 20,000 volumes of the collection.

III. Regulations and Opinions of "Administrative Agencies": At the Rutgers University Law Library the administrative law material, consisting of the "Federal Register," Code of Federal Regulations, and the series of reports of decisions of most of the federal administrative agencies are housed in one reading room together with the topical reporter covering the topic.

The neophyte adapting himself to the concepts of "stare decisis" or "precedent" becomes acutely aware of the need for and the existence of books that will enable him to locate and evaluate pertinent primary authority and of the dual purpose of "secondary authority."

Books in the Law Library enabling the user to locate and evaluate primary authority include: digests of case law, encyclopedias of case law, annotated reports, citators, books of definitions, and topical reporters.

Secondary authority includes legal periodicals and treatises. The Law Library currently receives about I 50 legal periodicals and is acquiring back issues whenever they are obtainable.

The lawyer's familiarity with the materials, their traditional functional arrangement, and the aids to research, both analytical and mechanical, incorporated in most law books, enables him to assume that if he is told where the particular group of materials is located, he will be able to proceed under his own power. When, however, he is faced with a problem, the answer to which lies in less frequently used materials, he assumes that professionally qualified staff members are available to help him. In fact, the legally trained person takes the availability of the entire organization so much for granted, that its necessity escapes him, unless it fails to function properly. It is obvious then that a qualified staff for a law library must have individuals professionally trained in both the legal and library professions.

\section{The Patrons}

A patron of the Law Library who requests aid or assistance from a member of the staff may notice that he is asked for information concerning his status. Law library patrons can be conveniently divided into faculty and the student body, the members of the legal profession, and the non-legal groups. The latter groups consist of nonlawyer professionals such as economists, accountants, patent agents, 
and individuals admitted to practice before government agencies; non-lawyer patrons such as hearing officers, students in other divisions of the University, the litigant appearing "pro se," and the layman.

If the patron is a member of the bar and he indicates a willingness to state his problem in specific terms, rather than "torts" or "assault," or "arrest," every effort is made to direct him to primary authority that will help him to predict the legal consequences of the operative fact situation. The extent and complexity of law and the quantity of materials make it difficult for lawyers to keep abreast of all the statutes, decisions, rules and regulations. Lawyers are as keenly aware of this as they are of their personal responsibility directly to the client for any conclusions and their effects. With this preface, it is easy to see why no barriers are interposed in the discussion of a problem with a member of the bar. The courtesies extended him are only limited by our primary obligation to our faculty and student body. These courtesies run the gamut of helping him to acquaint himself with the holdings of our collection, and to use materials in legal research more efficiently, calling his attention to literature he may have overlooked, permitting him to use the materials, aiding him in locating materials outside of the law field, locating the law of other jurisdictions, and permitting him to borrow, for production in court, the required materials.

\section{The Law Library and the Future}

The Law Library in an account to the legal profession for the five years that have elapsed since it became the Law Library of the State University could point to its well-rounded acquisitions as evidence of the development of a collection to serve all types of patrons. It provides the essential cultural and research materials for the student body, the faculty and the expanding curriculum. It provides the essential tools for the practitioner, and it contains one of the best representative collections of law materials within the State. Space does not permit us to elaborate, but a survey of all citations to secondary authority cited in I-7 N.J. Reports 342 and I-I 4 N.J. Superior 4 I 9 disclosed that only three items cited three or more times in either series of reports, were not available in the Rutgers University Law Library.

This account may suffice for today-but what of the endless tomorrows? Our objective is not to duplicate the magnificent collections 
of the largest law libraries. Harvard University has 656,000 volumes; Columbia, 300,000; Yale, 326,000; Michigan, 209,000; Minnesota, I 73,000; Northwestern, I 43,000. We do not strive for this impossible goal but rather set our sights for the larger law libraries that are or will be in the 100,000-volume group. The law school company there is and will be quite respectable. Washington University has I I I,230 volumes; New York University, I00,000; Illinois, 95,000; Iowa, 92,750; California, 91 ,4 I 7; Duke, 81,800; Ohio State, 85,498; Texas, 85,000; Virginia, 84,000; Louisiana State, 80,000; Stanford, 70,363.

For those who believe this to be an impractical goal and far beyond the requirements of the legal profession in New Jersey, one has only to point to the many law libraries controlled by, financed by, and maintained for the exclusive use of practitioners. These libraries, substantially limited to Anglo-American legal materials, have growth records that indicate their collections either have reached or will reach the roo,000-volume goal. The Philadelphia Bar Association has I I0,177; Social Law Library, I07,03 I; Chicago Law Institute, I08,850; N.Y. County Lawyers, 93,000; Cincinnati Library Association, 87,000; Cleveland Law Library, 84,038; Baltimore Bar Library, 78,785; and the Law Library Association of St. Louis, 64,449 .

That such a short-term expansion would neither be unique nor impossible is attested to by the histories of several law libraries. The need is evident, the possibility established. The probability depends entirely upon the availability of funds and the enthusiastic interest of those most concerned for its future usefulness. The first goal of the Rutgers University Law Library is to increase its holdings to roo,000 volumes. The following analysis of the Library's present holdings in terms of particular types of materials, set against an approximate ideal for a law library of 100,000 volumes, will show what acquisitions must be made to reach that goal.

$\begin{array}{lcc} & \begin{array}{c}\text { Rutgers } \\ I 95^{I}\end{array} & \text { Rutgers } \\ & & 1965 \\ \text { Appeal papers } & 80 & 4,000 \\ \text { Association proceedings } & 60 & 2,400 \\ \text { Att'y. Gen. opinions } & 20,034 & \mathrm{I}, 500 \\ \text { Court reports } & \mathrm{I}, 095 & 40,000 \\ \text { Digests } & & \mathrm{I}, 500\end{array}$


Encyclopedias

Rutgers

Rutgers

I95I

1965

$\mathrm{r}, 34 \mathrm{I}$

$\mathrm{I}, 400$

Foreign

Pamphlets

Periodicals

Shepards

Statutes

Texts

Trials

Other classes

Total holdings

\begin{tabular}{rr}
9 & 3,000 \\
5 & $\mathrm{I}, 000$ \\
$3,06 \mathrm{I}$ & $\mathrm{I} 2,000$ \\
68 & $\mathrm{I} 60$ \\
3,902 & 10,000 \\
4,152 & 10,000 \\
66 & 500 \\
$\mathrm{I}, \mathrm{I} 27$ & 10,000 \\
\hline 35,000 & 97,460
\end{tabular}

